\title{
Awareness of Ethical Issues when using an e-Learning System
}

\author{
Talib Ahmad Almseidein ${ }^{1}$, Omar Musa Klaif.Mahasneh ${ }^{2}$ \\ Department of basic and Applied Science, Shoubak University College \\ AL-Balqa Applied University, AL-Salt, Jordan
}

\begin{abstract}
Transformation to the digital system has made life easier, and the acceptance of the e-learning system in the academic life of students is a fact. Therefore, many educational organizations use the e-learning environment for teachinglearning activities. The present study has been conducted to evaluate the awareness of the undergraduate students to ethics and to determine if there is a difference according to gender and academic level variables when using an e-learning system at AlBalqa Applied University in Jordan. A self-questionnaire has been designed to measure the participant's awareness of ethics. It consists of 20 items classified in three ethical categories; Intellectual property rights, vandalism and Privacy. The results show that the awareness of students is low in all three categories regarding their commitment to the ethical issues when using an e-learning system. Result also show that there are no significant differences between undergraduate students' gender and academic level related to the awareness of ethical issues. Therefore, undergraduate students should be fully knowledgeable about ethical issues to avoid unethical behavior while using of the e-learning system.
\end{abstract}

Keywords-Code of ethics; ethical issues; e-learning

\section{INTRODUCTION}

Technological development at this current stage requires university students to use the computer and the Internet to gain knowledge. This has made it easier for university students to access many sources of information that can be used in education. Through advanced technology, university students can submit assignments, send files, and access necessary academic information and other services. Despite the benefits of using technology for students, it can increase the chances of falling into unethical behaviors [1].

The Education community has a belief that the traditional teaching-learning models do not meet the new challenges created by coming out technologies [2]. Therefore, many educational organizations turned towards the adoption of Information Communication Technology (ICT) to enhance their functions and goals. Nowadays, the quick growth of technology has changed the environment where life is affected by technology. The teaching-learning process relies on the employment of ICTs to achieve the educational goals by using e-learning [3]. Author of [4] stated that learning by facilitating and supporting through using ICT is an E-learning. Activities as managing data, storing information and sharing materials allow students and teachers to communicate and handle the assignments electronically and monitor the course through an e-learning system [5]. Besides, the distribution of study substances, evaluation of the capabilities of students and the enhancement of students through interaction between student and teacher is achieved through the use of ICTs in e-learning institutions. Recently, academic institutions are using elearning as an educational platform called Learning Management System (LMS) to its benefits as asynchronous and synchronous learning, improved communication and more collaboration [6]. Academic institutions use two modes of elearning. The first one is the Online mode where all activities are done through technology without using physical interaction between learner and instructor. The second one is the integration of face-to-face and online environments, known as a blended model [7]. In spite of e-learning advantages, it has aggravated the problems of cheating, plagiarism, and violation of privacy [8]. Furthermore, computer abuses, computer crimes, theft of data, equipment malfunctions, destruction from viruses, errors in handling and usage of data are ethical issues, which are considered to be threats to e-learning [9].

Professional international computer groups such as the (ACM, IEEE, and others) have developed written codes of ethics and make them obligatory for the members to follow. This interest is proof of the importance of understanding ethics [10].

This study aims to evaluate the student's awareness of ethics when using an e-learning system for the teachinglearning process. It explores if there is a difference in the awareness of the ethical issue when using the e-learning system according to gender and academic level variables. The paper is divided into six sections excluding the introduction section. Section II discusses the literature review. The research methodology is revealed in Section III. Section IV shows the result. Section V tackles the discussion, while the conclusion and recommendations are discussed in Section VI.

\section{LITERATURE REVIEW}

Chances for unethical behavior through students usually take place in e-Learning rather than traditional learning, which led the learners in e-learning to behave unethically [11, 12]. Ethical behavior is socially and morally acceptable, which is correspondent with right doings of the society [13]. In other words, ethics is a guide to making decisions about what is right and what is wrong.

Author in [14] has done a quantitative study to investigate the ethical issues that are related to the use of ICT by students at a higher education institution in the Eastern Capital province of South Africa. The number of undergraduate 
students was 312 and they sampled with the use of a questionnaire. The survey highlighted plagiarism, Software piracy, and cheating impact issues. The author concluded that ethical issues have to be covered in the curriculum when the author found that students were not aware of ethical issues as plagiarism and software piracy.

Author in [15] has proposed a model to integrate ethics in e-learning through virtual academic Counsellor to improve the ethical values of students and suggested recommendations to be followed which will help to produce ethically qualified graduates.

Authors of [7] indicated that Through the respondents' opinion in online courses the majority of students using the elearning system conducted unethical behavior as cheating. Authors of [8] have examined cheating behaviors such as plagiarism among 47 undergraduate education final years students. They concluded that using e-learning is exacerbating the problem of cheating.

Author in [3] has done a study by using two questionnaires to study the code of ethics of teaching and learning for an elearning system. The results indicated that teachers and students have to be aware of ethics and its future ramifications when using the e-learning system and activities offered by its demand to be advanced. Moreover, many researchers mentioned academic fraud is a very common ethical issue in eLearning, which is including assistance on examinations, plagiarism and the absence of an obligation to copyright [16-18].

According to The National Survey of Student Engagement (NSSE), 59\% of the United States students used e-learning programs have reported that they did some sort of academic fraud in their study, $27 \%$ did it very often while $32 \%$ often. [19].

\section{METHODOLOGY}

In this paper, a self-questionnaire is used as a research instrument. The questionnaire has one part which evaluates the student's awareness of ethics when using an e-learning system. It contains 20 items, which have been obtained from the code of ethics. The code of ethics is the standard of behavior that guides decisions and actions, based on duties that have been derived from core values [20]. In this study, the authors use the principles reported by (ACM and IEEE) to evaluate the student's awareness of ethics. The authors categorize the 20 items into three categories; Intellectual property rights, Vandalism and Privacy. A five-point Likert Scale has been used ranging from 5 (strongly agree), 4 (agree), 3 (neutral), 2 (disagree) and 1 (strongly disagree), based on the main items.

The collected data are processed and statistically analyzed by using (SPSS) Version 22. Range of means and their standard deviations values are used to evaluate the student's awareness of ethics when using an e-learning system. Larger values of the mean indicate higher levels of ethical awareness and lower values implied lower levels of ethical awareness. The strength of the ethical awareness is categorized into three levels based on the values of means. The authors adopt the following standard to indicate the degree of students' awareness of electronic ethics while using e-learning. There is low, moderate and high when the mean value is $\leq 2.32,3.66-$ 2.33 and $\geq 3.67$, respectively. Range $=(5-1) / 3=1.33$.
The reliability factor for the questionnaire is 0.85 which indicates a good level of reliability [21]. The questionnaire study has been applied to a random sample of 108 undergraduate students at Al-Balqa applied university (BAU). The BAU is one of the largest public universities in Jordan and has integrated e-learning in their degree program.

\section{RESULT}

The objective of this study is to evaluate the student's awareness of ethics and if there is a difference according to gender and academic level variables when using an e-learning system at the BAU for the teaching-learning process. The random study sample consists of 108 undergraduate students, their specializations and degrees are different. The awareness of students is grouped into three categories: Intellectual Property Rights, Vandalism and Privacy. The results of Means, standard deviations and awareness of students for each element measured in this study as shown in Tables I-III.

To determine if there is a difference awareness of ethical issue when using the e-learning system according to gender and academic level variables, ANCOVA variance analysis has been used and results shown in Table IV.

The Intellectual Property Rights consists of eight items. The items of this area are about copying and documentation. The values in Table I show that student's awareness is low for each item in this category.

TABLE. I. MEANS \pm SD OF INTELLECTUAL PROPERTY RightS CATEGORY

\begin{tabular}{|c|c|c|c|}
\hline Number & Item & Mean \pm SD & Awareness \\
\hline 1 & $\begin{array}{l}\text { I accept to copy my colleague's } \\
\text { duties and research without his } \\
\text { approval and send it through the e- } \\
\text { learning system. }\end{array}$ & $1.18 \pm .383$ & Low \\
\hline 2 & $\begin{array}{l}\text { Doing the assignments without } \\
\text { documenting references and send } \\
\text { them through the e-learning system. }\end{array}$ & $1.69 \pm .769$ & Low \\
\hline 3 & $\begin{array}{l}\text { Preparing research and reports } \\
\text { without documenting references and } \\
\text { send them through the e-learning } \\
\text { system }\end{array}$ & $1.81 \pm .767$ & Low \\
\hline 4 & $\begin{array}{l}\text { Use software applications without } \\
\text { prior permission from the original } \\
\text { product to do the assignments and } \\
\text { upload them through the e-learning } \\
\text { system }\end{array}$ & $1.69 \pm .606$ & Low \\
\hline 5 & $\begin{array}{l}\text { Use ready-made presentations from } \\
\text { the Internet without documenting the } \\
\text { reference and attribute it to me and } \\
\text { send it through the e-learning system }\end{array}$ & $1.67 \pm .641$ & Low \\
\hline 6 & $\begin{array}{l}\text { Photocopy documents from } \\
\text { references and send them through the } \\
\text { e-learning system without the } \\
\text { consent of the publisher }\end{array}$ & $1.64 \pm .703$ & Low \\
\hline 7 & $\begin{array}{l}\text { Ask others to get their homework } \\
\text { solutions and attribute it to me then } \\
\text { send it through the e-learning system }\end{array}$ & $1.65 \pm .701$ & Low \\
\hline 8 & $\begin{array}{l}\text { Use images and diagrams on the } \\
\text { Internet without documenting the } \\
\text { reference }\end{array}$ & $1.34 \pm .751$ & Low \\
\hline
\end{tabular}


Table II shows the results for the Vandalism category which consists of seven items, related to acts to harm others such as sending malicious files or destroying others' data. The values show that students' awareness is low for each item in this category.

The last category results are showed in Table III, as well as the values of each item in this category is low to determine the student's awareness.

Analysis of (ANCOVA) test has been applied to determine if is there a difference in the awareness of ethical issues when using the e-learning system according to gender and academic level variables. A significant level of $\alpha<0.05$ is adopted for the study. As shown in Table IV, there are no significant differences between undergraduate students' gender and academic level about awareness of ethical issues.

TABLE. II. MEANS \pm SD OF VANDALISM CATEGORY

\begin{tabular}{|l|l|l|l|}
\hline Number & Item & Mean \pm SD & Awareness \\
\hline 1 & $\begin{array}{l}\text { Send files filled with viruses through } \\
\text { the e-learning system. }\end{array}$ & $1.56 \pm .535$ & Low \\
\hline 2 & $\begin{array}{l}\text { Send files through the e-learning } \\
\text { system without making sure they are } \\
\text { safe. }\end{array}$ & $1.14 \pm .398$ & Low \\
\hline 3 & $\begin{array}{l}\text { Access the e-learning system from } \\
\text { other accounts without their } \\
\text { permission. }\end{array}$ & $1.98 \pm .192$ & Low \\
\hline 4 & $\begin{array}{l}\text { Open files via the e-learning system } \\
\text { without making sure they are safe }\end{array}$ & $1.76 \pm .609$ & Low \\
\hline 5 & $\begin{array}{l}\text { Send immoral files or links through } \\
\text { the e-learning system. }\end{array}$ & $1.99 \pm .837$ & Low \\
\hline 6 & $\begin{array}{l}\text { Send applications through the e- } \\
\text { learning system to destroy other } \\
\text { devices }\end{array}$ & $1.66 \pm .686$ & Low \\
\hline 7 & $\begin{array}{l}\text { I try to encrypt the data of others for } \\
\text { barter }\end{array}$ & $1.64 \pm .633$ & Low \\
\hline \multicolumn{2}{|l|}{ Total mean of this category = 1.67 } & \\
\hline
\end{tabular}

TABLE. III. MEANS \pm SD OF PRIVACY CATEGORY

\begin{tabular}{|l|l|l|l|}
\hline Number & Item & Mean \pm SD & Awareness \\
\hline 1 & $\begin{array}{l}\text { I give my colleagues the login } \\
\text { information for my account in the e- } \\
\text { learning system }\end{array}$ & $1.71 \pm .938$ & Low \\
\hline 2 & $\begin{array}{l}\text { Enter my colleagues' e-learning } \\
\text { accounts to solve their jobs and send } \\
\text { them through the e-learning system }\end{array}$ & $1.47 \pm .502$ & Low \\
\hline 3 & $\begin{array}{l}\text { Publish the files related to the } \\
\text { educational material in the e-learning } \\
\text { system via social networks }\end{array}$ & $1.44 \pm .584$ & Low \\
\hline 5 & $\begin{array}{l}\text { I preserve the files of others that I } \\
\text { found when using the chat in the e- } \\
\text { learning system }\end{array}$ & $1.76 \pm .594$ & Low \\
\hline 5 & $\begin{array}{l}\text { I use the assignment solution of my } \\
\text { old colleagues and send them } \\
\text { through the e-learning system } \\
\text { without their permission }\end{array}$ & $1.76 \pm .668$ & Low \\
\hline \multicolumn{2}{|l}{ Total mean of this category $=1.62$} & \\
\hline
\end{tabular}

TABLE. IV. COMPARISON OF ETHICAL ISSUES AWARENESS WHEN USING ELEARNING SYSTEM BY GENDER AND ACADEMIC LEVEL

\begin{tabular}{|l|l|l|l|l|l|}
\hline \multicolumn{2}{|l|}{ Dependent Variable: Ethics } & \multicolumn{5}{l|}{} \\
\hline Source & $\begin{array}{l}\text { Type III } \\
\text { Sum of } \\
\text { Squares }\end{array}$ & Df & $\begin{array}{l}\text { Mean } \\
\text { Square }\end{array}$ & F & Sig. \\
\hline $\begin{array}{l}\text { Corrected } \\
\text { Model }\end{array}$ & $45.401 \mathrm{a}$ & 7 & 6.486 & .763 & .619 \\
\hline Intercept & 46442.272 & 1 & 46442.272 & $5.466 \mathrm{E} 3$ & .000 \\
\hline Gender & 8.111 & 1 & 8.111 & .955 & .331 \\
\hline Level & 16.644 & 3 & 5.548 & .653 & .583 \\
\hline gender * level & 2.837 & 3 & .946 & .111 & .953 \\
\hline Error & 849.590 & 100 & 8.496 & & \\
\hline Total & 115035.000 & 108 & & & \\
\hline $\begin{array}{l}\text { Corrected } \\
\text { Total }\end{array}$ & 894.991 & 107 & & & \\
\hline a. R Squared $=.051$ (Adjusted R Squared = -.016) & & \\
\hline
\end{tabular}

\section{DISCUSSION}

Results show that the level of awareness of the issues associated with ethics when using an e-learning system by students is low. The results show that the Category of "Intellectual Property Rights" obtains the mean value (1.58); the second category "Vandalism" with a mean value of (1.67). The last mean value is (1.62). The results of this study, which has been conducted on a random sample of the students at BAU, indicate that the awareness of students of their commitment to the ethics when using an e-learning system comes low in all categories. This indicates that the students have unethical awareness about the discussed issues these categories. In light of the study results, it has been found that there are ethical issues among students when using e-learning, and this is confirmed in the study of [22] who highlighted the existence of ethical issues when using e-learning.

The authors believe that the reasons for this comes result of several factors, such as the difference in students' backgrounds and culture to determine what is ethical or immoral in the elearning environment, lack of include ethics within the curricula, the digital division and the lack of a general policy from academic institutions clarifying the ethics of dealing with the e-learning environment.

The result also indicates that there are no significant differences between the undergraduate students' gender and academic level regarding their awareness of ethical issues. Where the level of significances $(0.331,0.583)$ is higher than the level of significance $(0.05)$.

\section{CONCLUSION AND RECOMMENDATIONS}

The results of this study reveal that students at BAU have ethical issues when using e-learning system. To use e-learning system by the students within their academic period, the students should be fully knowledgeable about ethical issues to avoid unethical behavior. Authors of [23] discussed the inclusion of professional ethics topics in courses and developing e-learning on professional ethics so that students get an opportunity to understand and practice ethical 
judgments in the various aspects of ICT work. On the other hand, authors in [24] reported there is a need for academic institutions to espouse guidelines and ethical policies for the eLearning environment for preserving and supporting academic integrity.

The following are some recommendations for the institutions delivering e-Learning systems based on the results of the study:

- The inclusion of the subject of the ethical values as a seminar course within the student academic plan.

- The educational institution must build proper rules and policies for students involved in e-learning.

- The educational institution should adopt multimedia tools and monitoring tools in e-learning environment.

- Workshops or training must be held about ethical issues for students.

- Putting the necessary instructions on the optimal use of the e-learning system when student access his account to avoid any unethical behavior.

- Academic institutions should adopt a Code of ethics for their students when using the e-learning system seriously.

Finally, the study recommends the need to do similar studies on other universities in Jordan, intending to increase awareness and knowledge of ethical issues related to elearning system.

\section{REFERENCES}

[1] Jamil, M., and Shah, J. H. "Perception of undergraduates about computer and Internet ethics in Pakistan," Nigerian Journal of Technology (NIJOTECH), 33(4), 512-522, 2014.

[2] Nagi, K. "Solving Ethical Issues in eLearning," Special Issue of the International Journal of the Computer, the Internet and Management, 14(SP1), 2006.

[3] AL-Shehri, M. "Code of Ethics of Teaching-Learning for an e-Learning System," International Journal of Computer Applications, 166(5), 16-20, 2017.

[4] Masrom, M. "Technology Acceptance Model and E-learning," 12th International Conference on Education, Sultan Hassanal Bolkiah Institute of Education Universiti Brunei Darussalam,2017.

[5] Lonn, S., and Teasley, S. "Saving time or innovating practice: Investigating perceptions and uses of Learning Management Systems," Computer \& Education, 53(3), 686-694, 2009.

[6] Nawaz, A., and Kundi, G. M. "Demographic implications for the userperceptions of e-learning in higher education institutions of NW. FP," PAKISTAN, Electron. J. Inf. Syst. Dev. Ctries., 41(5), 1-17, 2010.

[7] Muhammad, A., Ghalib, M.F.MD., Ahmad, F., Naveed, Q.N., \& Shah, A. "A Study to Investigate State of Ethical Development in E-Learning," (IJACSA) International Journal of Advanced Computer Science and Application, 7(4), 284-289, 2016.
[8] Trushell, J., Byrne, K., and Simpson, R. "Cheating behaviours, the Internet and Education undergraduate students," Journal of Computer Assisted Learning, 28(2), 136-145, 2012

[9] Eftekhari, S. R. "e-Learning and e-Ethics," The Eighth International Conference on eLearning for Knowledge-Based Society, 23-24 February 2012, Thailand.

[10] Wood, G. "A cross cultural comparison of the contents of codes of ethics: USA, Canada and Australia," J. Bus. Ethics, . 25(4), 287-298, 2000.

[11] AbdulHafeez, M., Farooq, A., and Asadullah, R. "Resolving Ethical Dilemma in Technology Enhanced Education through smart mobile devices," Int. Arab J. e-Technology, 4(1), 25-31, 2015.

[12] Muhammad, A. H., Wahsheh, H. A., Shah, A., and Ahmad, F. "Ethical perspective of learning management system a model to support moral character of online learner," in Information and Communication Technology for The Muslim World (ICT4M), The 5th International Conference on, 2014, pp. 1-6, 2014.

[13] Bowden, P., and Smythe, V. "Theories on teaching \& training in ethics," EJBO Electronic Journal of Business Ethics and Organization Studies, 13(2), 19-26, 2008.

[14] Cilliers, L. "Evaluation of information ethical issues among undergraduate students: An exploratory study," South African Journal of Information Management 19(1), a767, 2017.

[15] Muhammad, A. "Integration of ethics in e-Learning through Virtual Academic Counsellor," 2018 International Conference on Innovation and Intelligence for Informatics, Computing, and Technologies (3ICT), Sakhier, Bahrain, 2018, pp. 1-6.

[16] Fess, R. A. "Cheating and plagiarism. Ethics and Higher Education." May, W. W. editor. New York: Macmillan Publishing Company and American Council on Education, 1990.

[17] Farisi, M. I. "Academic dishonesty in distance higher education: Challenges and Models for Moral Education in the Digital Era," Turkish Online Journal of Distance Education, 14(4), 176-195, 2013.

[18] Melissa, R., Olt, M.A., and M.S. "Ethics and Distance Education: Strategies for Minimizing Academic Dishonesty in Online Assessment," Online Journal of Distance Learning Administration, 5(3), 2002.

[19] Kuh, G. D. "The national survey of student engagement: Conceptual and empirical foundations," In R. Gonyea \& G. Kuh (Eds.), Using student engagement data in institutional research (New Directions for Institutional Research Series, no. 141, pp.5-20). San Francisco: JosseyBass, 2009.

[20] North, M. M., George, R., and North, S. M. " Computer Security and Ethics Awareness in University Environments: A Challenge for Management of Information Systems." ACM-SE 44 Proceedings of the 44 annual Southeast regional conference Pages 434-439, 2006.

[21] Bryman, A. "Social research methods, Oxford University Press," Oxford, 2012.

[22] Muhammad, A., Ahmad, F., and Shah, A. "Resolving Ethical Dilemma in Technology Enhanced Education through smart mobile devices," International Arab Journal of e-Technology, 4(1), 25-31, 2015.

[23] Nagarajan, K., Bevinakoppa, S. "Towards Understanding the Role of Institutional Pressures in Raising Awareness about Student Academic Integrity Issues in Australia," International Journal of Education and Learning Systems, 3, 93-104, 2018.

[24] A. Muhammad, A. Shaikh, Q. N. Naveed and M. R. N. Qureshi, "Factors Affecting Academic Integrity in e-Learning of Saudi Arabian Universities. An investigation using Delphi and AHP," in IEEE Access. doi: 10.1109/ACCESS.2020.2967499. 